\title{
Absence of toll-like receptor 9 Pro99Leu polymorphism in
}

\section{cervical cancer [version 1; peer review: 2 approved with}

\section{reservations, 1 not approved]}

\author{
Alex Chauhan (iD1, Nilesh Pandey¹, Nitin Raithatha², Purvi Patel³, Ajesh Desai4, \\ Neeraj Jain ${ }^{1}$
}

1P D Patel Institute of Applied Sciences, Charotar University of Science and Technology (CHARUSAT), Changa, India 2Department of Obstetrics and Gynaecology, Pramukh Swami Medical College, Shree Krishna Hospital, Karamsad, India ${ }^{3}$ Department of Obstetrics and Gynaecology, Sir Sayajirao General Hospital and Medical College Baroda, Vadodara, India ${ }^{4}$ Department of Obstetrics and Gynaecology, GMERS Medical College and Hospital, Ahmedabad, India

V1 First published: 17 May 2018, 7:606

https://doi.org/10.12688/f1000research.14840.1

Latest published: 30 Aug 2018, 7:606

https://doi.org/10.12688/f1000research.14840.2

\section{Abstract}

Background: Toll-like receptor 9 (TLR9) plays a key role in the elimination of viral pathogens by recognising their CpG DNA. Polymorphisms in the $T L R 9$ gene may influence their recognition and subsequent elimination. Therefore, the present study was designed to elucidate the role of a rare unexplored TLR9 gene polymorphism C296T/ Pro99Leu (rs5743844) in cervical cancer susceptibility among Indian women.

Methods: The genotyping of TLR9 Pro99Leu polymorphism in 110 cervical cancer patients and 141 healthy controls was performed by polymerase chain reaction-restriction fragment length polymorphism (PCR-RFLP).

Results: The genotype frequency detected in both cervical cancer and control populations was 1.0 (CC), 0.0 (CT) and 0.0 (TT); while the allele frequency was found to be $1.0(\mathrm{C})$ and $0.0(\mathrm{~T})$.

Conclusions: The present study results demonstrate no involvement of TLR9 C296T/ Pro99Leu polymorphism in cervical cancer susceptibility and supports worldwide minor allele frequency (MAF) $(0.0002)$ status of the same as no nucleotide variation was detected in any of the study participants.

Keywords

Cervical cancer, TLR9, Polymorphism, Genotypic frequency,

Susceptibility

\section{Open Peer Review \\ Approval Status $\mathrm{X}$ \\ 12 \\ 23 \\ version 2 \\ (revision) \\ 30 Aug 2018 \\ version 1 \\ 17 May 2018

view \\ $\times$ \\ view \\ s \\ $\times$ \\ view \\ s \\ $?$ \\ view \\ 1. Gopeshwar Narayan (D), Banaras Hindu \\ University, Varanasi, India \\ 2. Balraj Mittal, Babasaheb Bhimrao Ambedkar University, Lucknow, India \\ 3. Bhudev C. Das, University of Delhi, New Delhi, India \\ Any reports and responses or comments on the article can be found at the end of the article.}


Corresponding author: Neeraj Jain (neerajjain.as@charusat.ac.in)

Author roles: Chauhan A: Formal Analysis, Investigation, Methodology, Visualization, Writing - Original Draft Preparation; Pandey N: Formal Analysis, Investigation, Writing - Review \& Editing; Raithatha N: Investigation, Resources, Writing - Review \& Editing; Patel P: Investigation, Resources, Writing - Review \& Editing; Desai A: Investigation, Resources, Writing - Review \& Editing; Jain N:

Conceptualization, Funding Acquisition, Project Administration, Supervision, Validation, Writing - Review \& Editing

Competing interests: No competing interests were disclosed.

Grant information: The study was funded by Charotar University of Science and Technology (CHARUSAT).

The funders had no role in study design, data collection and analysis, decision to publish, or preparation of the manuscript.

Copyright: ( $) 2018$ Chauhan A et al. This is an open access article distributed under the terms of the Creative Commons Attribution License, which permits unrestricted use, distribution, and reproduction in any medium, provided the original work is properly cited. Data associated with the article are available under the terms of the Creative Commons Zero "No rights reserved" data waiver (CCO 1.0 Public domain dedication).

How to cite this article: Chauhan A, Pandey N, Raithatha $\mathrm{N}$ et al. Absence of toll-like receptor 9 Pro99Leu polymorphism in cervical cancer [version 1; peer review: 2 approved with reservations, 1 not approved] F1000Research 2018, 7:606 https://doi.org/10.12688/f1000research.14840.1

First published: 17 May 2018, 7:606 https://doi.org/10.12688/f1000research.14840.1 


\section{Introduction}

Cervical cancer is the fourth-most common cancer among women globally and second leading cause of cancer-related deaths in Indian women ${ }^{1}$. Although persistent infection of high-risk human papillomavirus (hrHPV) is considered as the chief causative agent of cervical cancer, variations in host genetic make-up do influence the risk of acquiring HPV infection, and susceptibility to cervical carcinogenesis ${ }^{2-4}$. In this context, variations in Toll-like receptors (TLRs), that play a crucial role in activating immune response by identifying pathogenassociated molecular patterns, have drawn significant attention, as single nucleotide polymorphisms (SNPs) in TLR genes have been shown to alter susceptibility to many infections and human diseases including cancer $^{5-8}$

Ten functional TLR genes are known in humans ${ }^{9}$, one of which, the TLR9 gene product, recognizes microbial DNA motifs $^{5,10,11}$. Frequently analysed $T L R 9$ SNPs G2848A and -1486 T/C have been suggested to alter cervical cancer susceptibility ${ }^{12-15}$, but no report is available elucidating the role of TLR9 Pro99Leu polymorphism in cancer. Although TLR9 Pro99Leu is a rare population SNP with a global minor allele frequency (MAF) of 0.0002 as reported in the single nucleotide polymorphism database (dbSNP), in-vitro analysis has revealed its significant role in DNA ligand hyporesponsiveness ${ }^{16}$. Considering the fact that cervical cancer is largely caused by hrHPV infection and TLR9 has the ability to respond to viral DNA, the present study was designed to elucidate the association of the TLR9 Pro99Leu polymorphism with cervical cancer.

\section{Methods}

Biological specimens

Biopsies from 110 cervical cancer patients and cervical smears from 141 healthy volunteers were collected from Shree Krishna Hospital, Anand; Sir Sayajirao General Hospital, Vadodara; and GMERS Hospital, Ahmedabad, India. The samples were collected from 2012 to 2017. The cancer biopsies and healthy cervical smears were histopathologically and cytologically confirmed. The clinical staging of cervical cancer samples was done as per The International Federation of Gynecology and Obstetrics (FIGO) guidelines.

\section{DNA isolation and genetic analysis}

DNA was isolated from cervical cancer biopsies and cervical smears by standard phenol-chloroform extraction method ${ }^{17}$. In the case of a low number of cervical cells, a spin-column based DNA isolation kit (Macherey-Nagel, Germany; Cat\# 740952.50) was utilized as per manufacturer's instructions. The quality and quantity of DNA was determined using ethidium bromide-stained $1 \%$ agarose gel on GelDoc system (BioRad, USA) as well as a NanoDrop 2000 (Thermofisher, USA). The TLR9 Pro99Leu polymorphism was detected using polymerase chain reaction -restriction fragment length polymorphism (PCR-RFLP) method as described by Kubarenko et al. ${ }^{16}$ Briefly, a $25 \mu$ PCR mix contained $0.1 \mu \mathrm{M}$ each of forward and reverse primer (Imperial Life Sciences, India), $0.1 \mathrm{mM}$ dNTP mix (Invitrogen, USA; Cat\# 18427088), 2.5mM MgCl 2 (Vivantis, USA; Cat\# RB0204), 1 unit Taq DNA polymerase (Kapabiosystems, USA; Cat\# KK1015) and 100 to 150 ng genomic DNA. The PCR was run on an MJ Mini thermal cycler (BioRad, USA).

Upon confirmation of 337 bp PCR product on 2\% ethidium bromide-stained agarose gel, $10 \mu \mathrm{l}$ PCR product was digested with BslI restriction enzyme (New England Biolabs, USA; Cat\# $\mathrm{R} 0555 \mathrm{~S})$ at $55^{\circ} \mathrm{C}$ overnight, separated on $12 \%$ polyacrylamide gel and analysed on a GelDoc system (BioRad, USA) for genotype identification. The details of PCR conditions and parameters for genotype consideration are mentioned in Table 1 and Table 2 respectively. To confirm the PCR-RFLP results, we performed Sanger sequencing of five randomly selected cervical cancer as well as control samples. All the sequencing reactions were performed on 3730xl DNA Analyzer (Applied Biosystems, USA) using BigDye ${ }^{\mathrm{TM}}$ Terminator v3.1 kit (Applied Biosystems, USA; Cat\# 4337454) as per manufacturer's instructions. The $10 \mu \mathrm{l}$ sequencing reaction was comprised of $7.0 \mu \mathrm{l} \mathrm{BigDye} \mathrm{TM}^{\mathrm{TM}}$ Terminator v3.1 Ready Reaction Mix, 10pmol forward

Table 1. Details of TLR9 C296T/ Pro99Leu specific PCR.

\begin{tabular}{|c|c|c|c|}
\hline \multicolumn{1}{|c|}{ Primer Sequence $\left(\mathbf{5}^{\prime}-\mathbf{3}^{\prime}\right)$} & Thermal Profile & $\begin{array}{c}\text { PCR } \\
\text { Product }\end{array}$ & $\begin{array}{c}\text { Visualized } \\
\text { on }\end{array}$ \\
\hline FP: GGATGTTGGTATGGCTGAGG & $\left(95^{\circ} \mathrm{C}-5^{\prime}\right) 1$ & & \\
\hline RP: AACTGCAACTGGCTGTTCCT & $\left(95^{\circ} \mathrm{C}-45^{\prime \prime}, 56^{\circ} \mathrm{C}-1^{\prime}, 72^{\circ} \mathrm{C}-30^{\prime \prime}\right) 35$ & $337 \mathrm{bp}$ & $2 \%$ Agarose \\
& $\left(72^{\circ} \mathrm{C}-10^{\prime}\right) 1$ & & \\
\hline
\end{tabular}

Abbreviations: TLR9, Toll-like receptor 9; FP, forward Primer; RP, Reverse Primer; PCR, Polymerase Chain Reaction; bp, base pairs

Table 2. Parameters for genotypes consideration of TLR9 C296T/ Pro99Leu polymorphism.

\begin{tabular}{|l|l|l|}
\hline Enzyme & Digested Products (bp) & Genotype \\
\hline \multirow{3}{*}{ BsII } & $166+136+35$ & CC (Pro/Pro) \\
\hline & $201+166+136+35$ & CT (Pro/Leu) \\
\hline $201+136$ & TT (Leu/Leu) \\
\hline
\end{tabular}


primer and 50ng PCR product. The sequencing results were analyzed on Sequencing Analysis Software version 5.3.1 (Applied Biosystems, USA).

\section{Statistical analysis}

Statistical analysis was performed on GraphPad Prism version 5.00 for Windows (GraphPad Software, USA). Age of patients and controls were compared using two-sided Student's t-test. Due to the presence of single genotype across all the samples no additional statistical association was performed.

\section{Results}

Demographic and clinical characteristics

The average age of cervical cancer patients $(52.43 \pm 11.78$ years) and controls (51.8 \pm 11.35 years) was comparable without any statistically significant difference $(\mathrm{p}=0.668)$. Histopathologic analysis revealed all the cervical cancer cases to be of squamous cell carcinoma type. According to FIGO analysis, 9 (8.2\%), $39(35.5 \%), 55(50 \%)$ and $7(6.3 \%)$ patients belonged to Stage I, II, III and IV respectively.

\section{TLR9 Pro99Leu polymorphism}

PCR amplification revealed the presence of a single intact band of 337 bp (Figure 1; Dataset $1^{18}$ ). A single genotype CC (Pro/Pro) was detected across all the sample types (Table 3; Dataset $2^{19}$ ) which was evident by the presence of $166 \mathrm{bp}, 136 \mathrm{bp}$ and 35 bp DNA bands after RFLP assay (Figure 2; Dataset $3^{20}$ ). Sanger sequencing of the randomly selected PCR products corroborated with RFLP results (Figure 3; Dataset $4^{21}$ ).

Dataset 1. Raw, unedited agarose gel images of PCR amplification of TLR9 gene segment for C296T/ Pro99Leu polymorphism from 50 samples consisting of 26 controls and 24 cervical cancer cases http://dx.doi.org/10.5256/f1000research.14840.d203405

Figure 1 is a representative picture of the same.

Dataset 2. Age, clinical stage and TLR9 genotype status among cervical cancer patients as well as age and $T L R 9$ genotype status among controls

http://dx.doi.org/10.5256/f1000research.14840.d203406

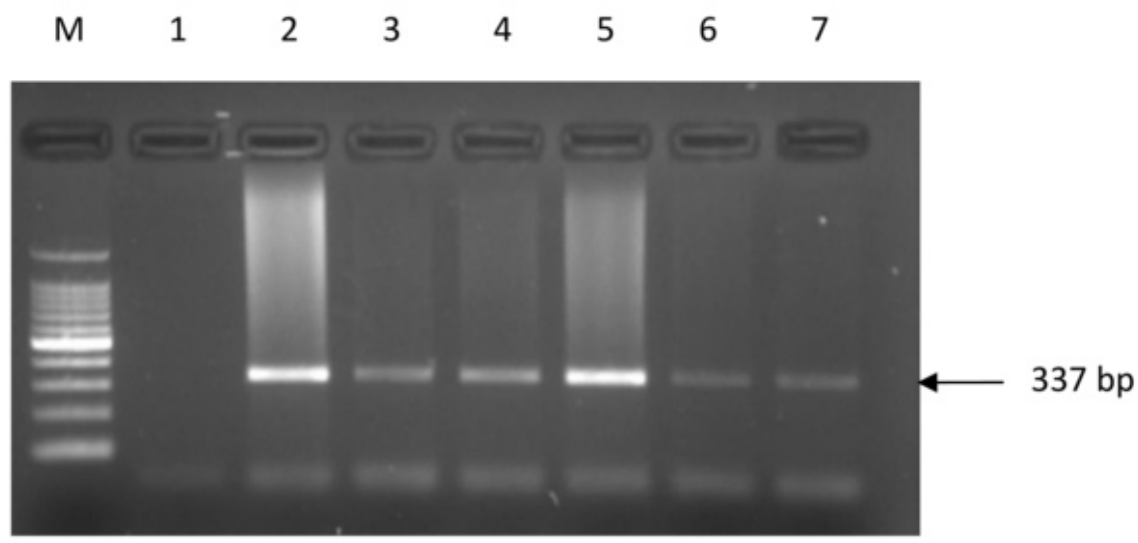

Figure 1. Representative PCR picture showing amplification of TLR9 gene segment for C296T/ Pro99Leu gene polymorphism on ethidium bromide-stained $\mathbf{2} \%$ agarose gel. Lane $\mathrm{M}$ is $100 \mathrm{bp}$ molecular marker (Takara, Japan; Cat\# RR820A), Lane 1 is negative control and Lanes 2-7 are tumor DNA showing PCR products of 337 bp. (Abbreviations: PCR, Polymerase Chain Reaction; TLR9, Toll-like receptor 9; bp, base pair).

\begin{tabular}{|c|c|c|}
\hline Genotype & $\begin{array}{l}\text { Cervical Cancer } \\
n(\%)\end{array}$ & $\begin{array}{l}\text { Controls } \\
n(\%)\end{array}$ \\
\hline $\mathrm{CC}$ & $110(100.0)$ & $141(100.0)$ \\
\hline CT & $0(0.0)$ & $0(0.0)$ \\
\hline TT & $0(0.0)$ & $0(0.0)$ \\
\hline \multicolumn{3}{|l|}{ Allele } \\
\hline C & $220(100.0)$ & $282(100.0)$ \\
\hline $\mathbf{T}$ & $0(0.0)$ & $0(0.0)$ \\
\hline
\end{tabular}




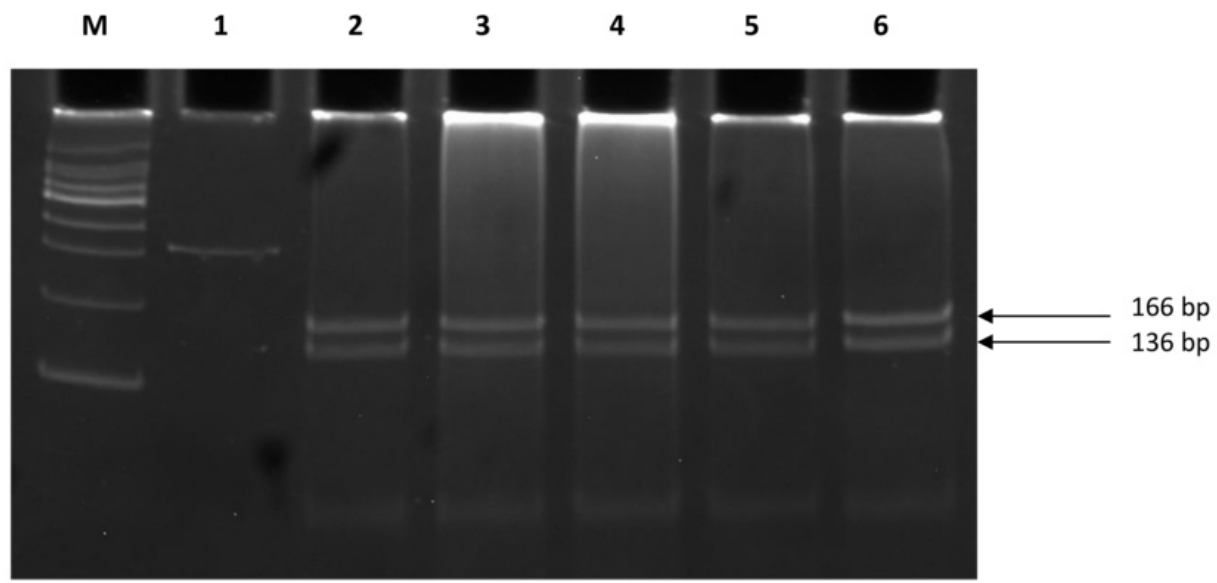

Figure 2. Representative PAGE picture of RFLP results for TLR9 C296T/ Pro99Leu polymorphism on 12\% polyacrylamide gel. Lane M is 100 bp molecular marker, Lane 1 is undigested PCR product and Lanes 2 to 6 are showing digested PCR products of 166 bp and $136 \mathrm{bp}$ (35 bp band is not visible) by Bs/l enzyme representing CC genotype. (Abbreviations: PAGE, Polyacrylamide Gel Electrophoresis; RFLP, Restriction Fragment Length Polymorphism).

A

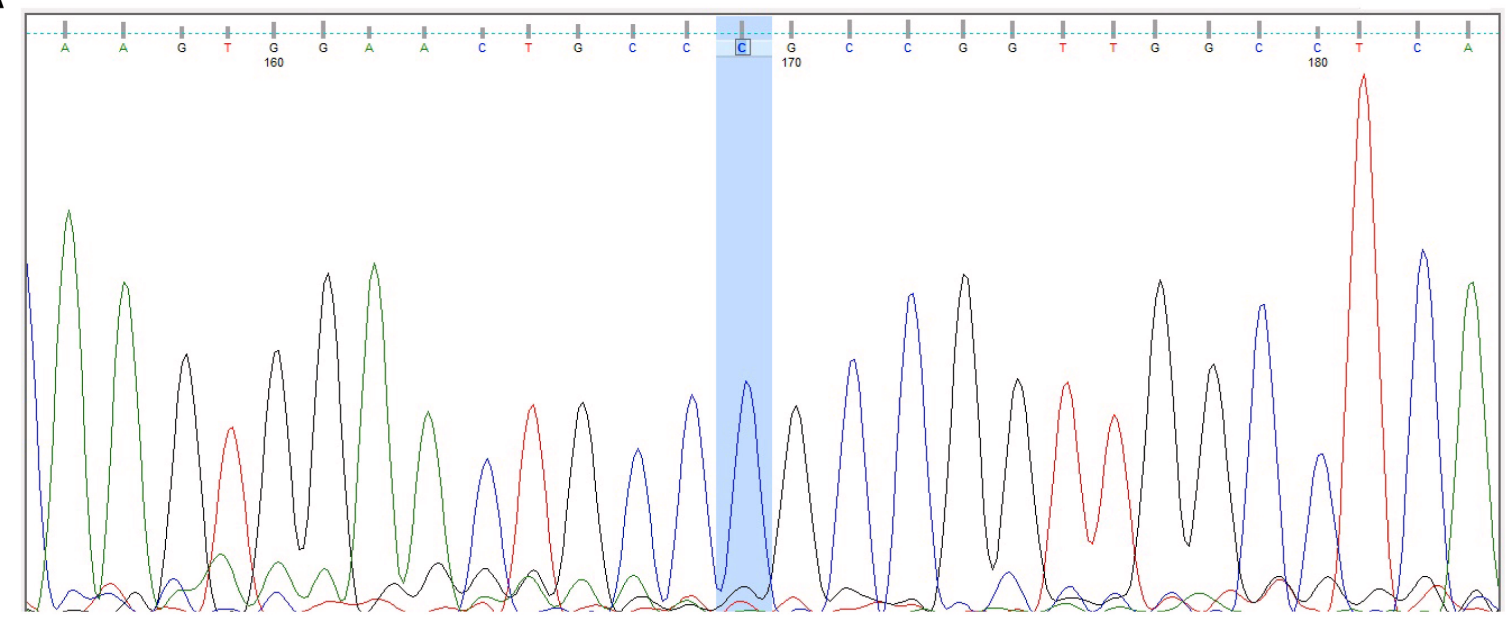

B

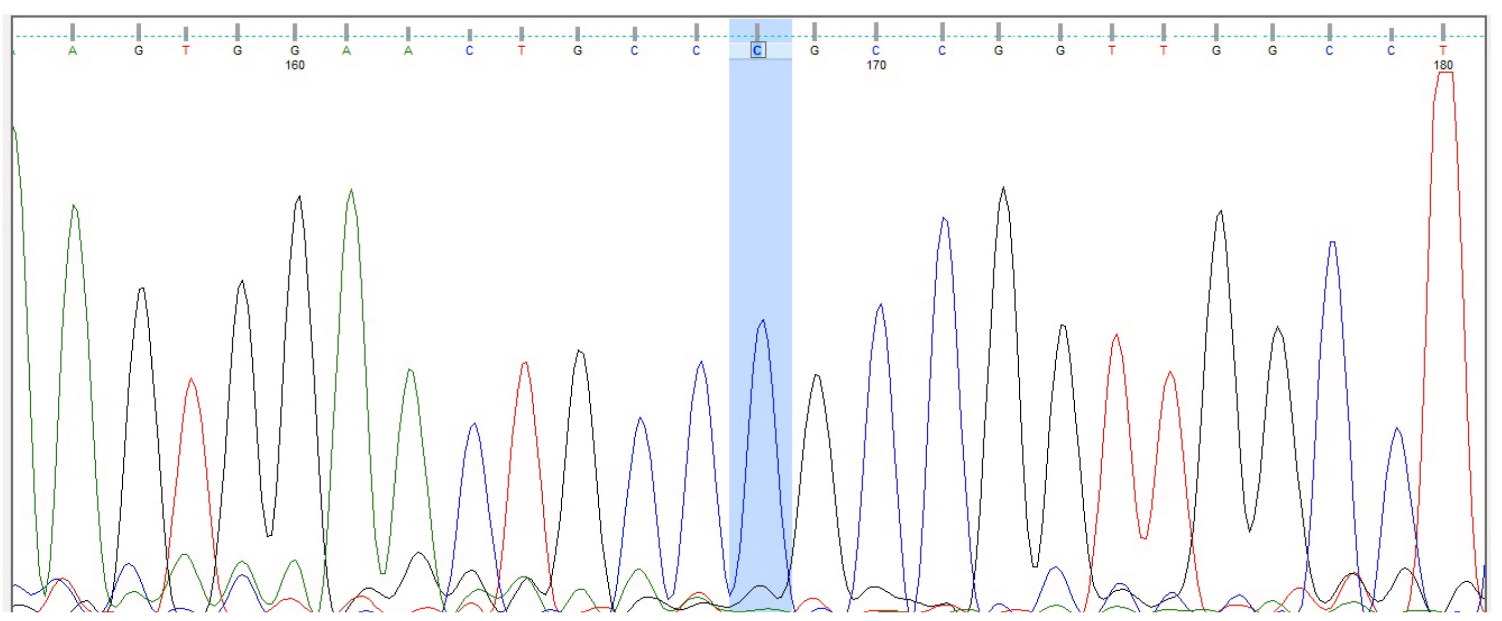

Figure 3. Sanger sequence electropherogram of $(\mathbf{A})$ a healthy individual and (B) patient showing single peak (highlighted) of C allele of TLR9 C296T/ Pro99Leu SNP representing CC genotype. (Abbreviations: SNP, Single Nucleotide Polymorphism). 
Dataset 3. Raw, unedited polyacrylamide gel electrophoresis images of 27 controls and 24 cervical cancer PCR amplified products that underwent restriction fragment length polymorphism (RFLP) analysis

http://dx.doi.org/10.5256/f1000research.14840.d203407

Figure 2 is a representative picture of the same.

Dataset 4. Nucleotide sequences spanning TLR9 gene segment for C296T single nucleotide polymorphism, obtained after performing Sanger sequencing on five samples each of cervical cancer and healthy controls

http://dx.doi.org/10.5256/f1000research.14840.d203408

The sequencing results confirm the restriction fragment length polymorphism (RFLP) analysis that represents single genotype $\mathrm{CC}$ among all the study participants. Figure $3 \mathrm{~A}$ and $\mathrm{B}$ are representative electropherograms of the TLR9 C296T CC genotype as evident by the presence of single peak of $\mathrm{C}$ allele.

\section{Discussion}

Although hrHPV infection is the primary etiological agent of cervical carcinogenesis, the role of host genetic factors, especially those associated with body immunity such as TLRs, cannot be ignored. TLR9 SNPs -1486 T/C and G2848A have been found to be contradictorily associated with cervical cancer risk. In Polish and Mexican populations both TLR9 -1486 T/C and G2848A polymorphisms were suggested to be risk factors for cervical carcinogenesis ${ }^{12,14}$. In two independent studies on Chinese population, a positive association with TLR9 G2848A SNP was detected ${ }^{22,23}$ but no involvement of TLR9 -1486 T/C was found $^{23}$, however, the other study suggested $-1486 \mathrm{~T} / \mathrm{C}$ was not a contributory factor to cervical carcinogenesis ${ }^{13}$. From India, a single report on North Indian patients revealed a marginal role of TLR9 G2848A polymorphism with cervical cancer risk ${ }^{15}$.

To date, no report is available on the rare TLR9 Pro99Leu polymorphism in cancer, which has been shown to be associated with DNA ligand hyporesponsiveness in HeLa cell lines ${ }^{16}$. Considering the fact that cervical cancer is majorly caused by hrHPV infection and the TLR9 Pro99Leu polymorphism is associated with DNA ligand hyporesponsiveness, the present study investigated, for the first time, the role of the TLR9 Pro99Leu polymorphism in cervical cancer susceptibility. This is also the first report to study this polymorphism in any of the cancer types globally. Our results revealed the presence of a single genotype CC (Pro/Pro) among cases and controls, demonstrating no significance of the Pro99Leu polymorphism to cervical cancer susceptibility. A complete absence of Pro99Leu in our study population corroborates with the report of Lee and group (2006) where neither controls nor lung tuberculosis and sarcoidosis patients had the TLR9 Pro99Leu polymorphism ${ }^{24}$. Similarly, the Pro99Leu polymorphism was not detected among healthy Caucasians as well as pneumococcal disease, bacteraemia, and leprosy patients ${ }^{16}$. Moreover, according to dbSNP, the global MAF of this polymorphism is 0.0002 , and our results, albeit on a smaller cohort, do solicit its rare polymorphism status. Therefore, a direct role of this SNP in cancer, as well as other diseases, seems a remote possibility. Nonetheless, a comprehensive analysis of a larger cohort covering a varied ethnic population globally is suggested to comprehend its role in microbial infection and/or disease susceptibility including cancer.

\section{Conclusion}

The preliminary data obtained from the present study does not suggest a role for the TLR9 Pro99Leu polymorphism in cervical cancer susceptibility. However, analysis on a larger cohort worldwide may provide more insights into the frequency distribution of Pro99Leu polymorphism and reveal its influential role in various human diseases including cancer.

\section{Data availability}

Dataset 1. Raw, unedited agarose gel images of PCR amplification of TLR9 gene segment for C296T/ Pro99Leu polymorphism from 50 samples consisting of 26 controls and 24 cervical cancer cases. Figure 1 is a representative picture of the same. 10.5256/f1000research.14840.d203405 ${ }^{18}$

Dataset 2. Age, clinical stage and TLR9 genotype status among cervical cancer patients as well as age and TLR 9 genotype status among controls. 10.5256/f1000research.14840.d203406 ${ }^{19}$

Dataset 3. Raw, unedited polyacrylamide gel electrophoresis images of 27 controls and 24 cervical cancer PCR amplified products that underwent restriction fragment length polymorphism (RFLP) analysis. Figure 2 is a representative picture of the same. 10.5256/f1000research.14840.d20340 $7^{20}$

Dataset 4. Nucleotide sequences spanning TLR9 gene segment for C296T single nucleotide polymorphism, obtained after performing Sanger sequencing on five samples each of cervical cancer and healthy controls. The sequencing results confirm the restriction fragment length polymorphism (RFLP) analysis that represents single genotype $\mathrm{CC}$ among all the study participants. Figure $3 \mathrm{~A}$ and $\mathrm{B}$ are representative electropherograms of the TLR9 C296T CC genotype as evident by the presence of single peak of C allele. 10.5256/f1000research.14840.d203408 ${ }^{21}$

\section{Ethical considerations}

The research was carried out following due approval from ethics committee of all the participating institutes. Participants were verbally informed and explained about the study, and were provided with an information sheet. Written informed consent was obtained from the participants who agreed to enrol in the present study. Personal information of all the study subjects was kept confidential.

\section{Competing interests}

No competing interests were disclosed.

\section{Grant information}

The study was funded by Charotar University of Science and Technology (CHARUSAT).

The funders had no role in study design, data collection and analysis, decision to publish, or preparation of the manuscript.

\section{Acknowledgement}

Authors thank Dr. Anjana Chauhan, Gynec Cancer Surgeon, Ex Associate Professor, Gujarat Cancer and Research Institute, Ahmedabad, India for stimulating discussions. 
1. Ferlay J, Soerjomataram I, Dikshit R, et al.: Cancer incidence and mortality worldwide: sources, methods and major patterns in GLOBOCAN 2012. Int $\mathrm{J}$ Cancer. 2015; 136(5): E359-386.

PubMed Abstract | Publisher Full Text

2. Walboomers JM, Jacobs MV, Manos MM, et al:: Human papillomavirus is a necessary cause of invasive cervical cancer worldwide. J Pathol. 1999; 189(1): 12-9. PubMed Abstract | Publisher Full Text

3. Chattopadhyay K: A comprehensive review on host genetic susceptibility to human papillomavirus infection and progression to cervical cancer. Indian $\mathrm{J}$ Hum Genet. 2011; 17(3): 132-44.

PubMed Abstract | Publisher Full Text | Free Full Text

4. Leo PJ, Madeleine MM, Wang S, et al.: Defining the genetic susceptibility to cervical neoplasia-A genome-wide association study. PLoS Genet. 2017; 13(8): e1006866.

PubMed Abstract | Publisher Full Text | Free Full Text

5. Kumar H, Kawai T, Akira S: Toll-like receptors and innate immunity. Biochem Biophys Res Commun. 2009; 388(4): 621-5.

PubMed Abstract | Publisher Full Text

6. Schröder NW, Schumann RR: Single nucleotide polymorphisms of Toll-like receptors and susceptibility to infectious disease. Lancet Infect Dis. 2005; 5(3) 156-64.

PubMed Abstract | Publisher Full Text

7. Misch EA, Hawn TR: Toll-like receptor polymorphisms and susceptibility to human disease. Clin Sci (Lond). 2008; 114(5): 347-60. PubMed Abstract | Publisher Full Text

8. El-Omar EM, Ng MT, Hold GL: Polymorphisms in Toll-like receptor genes and risk of cancer. Oncogene. 2008; 27(2): 244-52.

PubMed Abstract | Publisher Full Text

9. Gomaz AN: The polymorphisms in Toll-like receptor genes and cancer risk. 2012; 114(4): 461-9. Reference Source

10. Kawai T, Akira S: Toll-like receptor and RIG-I-like receptor signaling. Ann NY Acad Sci. 2008; 1143: 1-20.

PubMed Abstract | Publisher Full Text

11. Hemmi $\mathrm{H}$, Takeuchi $\mathrm{O}$, Kawai $\mathrm{T}$, et al.: A Toll-like receptor recognizes bacterial DNA. Nature. 2001; 408(6813): 740-5. PubMed Abstract | Publisher Full Text

12. Roszak A, Lianeri M, Sowińska A, et al:: Involvement of Toll-like Receptor 9 polymorphism in cervical cancer development. Mol Biol Rep. 2012; 39(8): 8425-30.

PubMed Abstract | Publisher Full Text | Free Full Text

13. Chen X, Wang S, Liu L, et al:: A genetic variant in the promoter region of
Toll-like receptor 9 and cervical cancer susceptibility. DNA Cell Biol. 2012; 31(5): 766-71.

PubMed Abstract | Publisher Full Text

14. Martínez-Campos C, Bahena-Román M, Torres-Poveda K, et al:: TLR9 gene polymorphism $-1486 \mathrm{~T} / \mathrm{C}$ (rs187084) is associated with uterine cervical neoplasm in Mexican female population. $J$ Cancer Res Clin Oncol. Springer Berlin Heidelberg; 2017; 143(12): 2437-2445.

Berlin Heidelberg; 2017; 143(12): 2437-2445
PubMed Abstract | Publisher Full Text

15. Pandey S, Mittal B, Srivastava M, et al:: Evaluation of Toll-like receptors 3 (c.1377C/T) and 9 (G2848A) gene polymorphisms in cervical cancer susceptibility. Mol Biol Rep. 2011; 38(7): 4715-21.

PubMed Abstract | Publisher Full Text

16. Kubarenko $\mathrm{AV}$, Ranjan $\mathrm{S}$, Rautanen $\mathrm{A}$, et al:: A naturally occurring variant in human TLR9, P99L, is associated with loss of CpG oligonucleotide responsiveness. J Biol Chem. 2010; 285(47): 36486-94. PubMed Abstract | Publisher Full Text | Free Full Text

17. Sambrook J, Fritsch E, MT: Molecular Cloning: A Laboratory Manual. Cold Spring Harbor, NY: Cold Spring Harbor Laboratory Press; 1989.

18. Chauhan A, Pandey N, Raithatha N, et al.: Dataset 1 in: Absence of toll-like receptor 9 Pro99Leu polymorphism in cervical cancer. F1000Research. 2018. Data Source

19. Chauhan A, Pandey N, Raithatha N, et al.: Dataset $\mathbf{2}$ in: Absence of toll-like receptor 9 Pro99Leu polymorphism in cervical cancer. F1000Research. 2018. Data Source

20. Chauhan A, Pandey N, Raithatha N, et al.: Dataset $\mathbf{3}$ in: Absence of toll-like receptor 9 Pro99Leu polymorphism in cervical cancer. F1000Research. 2018. Data Source

21. Chauhan A, Pandey N, Raithatha N, et al:: Dataset 4 in: Absence of toll-like receptor 9 Pro99Leu polymorphism in cervical cancer. F1000Research. 2018. Data Source

22. Jin Y, Qiu S, Shao N, et al:: Association of toll-like receptor gene polymorphisms and its interaction with HPV infection in determining the susceptibility of cervical cancer in Chinese Han population. Mamm Genome. Springer US; 2017; 28(5-6): 213-9. PubMed Abstract | Publisher Full Text

23. Lai ZZ, Ni-Zhang, Pan XL: Toll-like receptor 9 (TLR9) gene polymorphisms associated with increased susceptibility of human papillomavirus-16 infection in patients with cervical cancer. J Int Med Res. 2013; 41(4): 1027-36. PubMed Abstract | Publisher Full Text

24. Lee PL, West C, Crain K, et al:: Genetic polymorphisms and susceptibility to lung disease. J Negat Results Biomed. 2006; 5: 5 . PubMed Abstract | Publisher Full Text | Free Full Text 


\section{Open Peer Review}

\section{Current Peer Review Status: ? X ?}

\section{Version 1}

Reviewer Report 02 August 2018

https://doi.org/10.5256/f1000research.16153.r34120

(C) 2018 Das B. This is an open access peer review report distributed under the terms of the Creative Commons Attribution License, which permits unrestricted use, distribution, and reproduction in any medium, provided the original work is properly cited.

\section{Bhudev C. Das}

Dr. B. R. Ambedkar Center for Biomedical Research, University of Delhi, New Delhi, India

I have gone through the manuscript entitled "Absence of toll-like receptor 9 Pro99Leu polymorphism in cervical cancer" submitted by Alex Chauhan et al. for its publication in F1000Research. The authors have studied the polymorphisms of Toll-like receptor 9 (TLR9) Pro99Leu polymorphism in cervical cancer to examine its role in cervical carcinoma in elimination of viral pathogens though recognition of CpG islands. It is suggested that polymorphism of TLR9 gene may influence the recognitions of the above DNA sequence leading to elimination of infection. The authors have used as many as 110 cervical cancer samples and normal cervical smears from 141 healthy controls and employed PCR-RFLP and sequencing methods for detection of genotype variation. The authors could not find any variation in genotypes of TLR9 hence authors concluded that the specific polymorphism C296T/Pro99Leu has no role in cervical cancer.

This is a very clean and straight forward study which could not find any link between TLR9 polymorphism and cervical cancer. The data and the figures presented including PCR and PCRRFLP and sequencing pictures are excellent and convincing. However, there are few points which need to be clarified/corrected before the manuscript is accepted and indexed. My comments are as follows:

1. The whole study is based on only one TLR9 gene polymorphism. Authors need to very clearly justify their choice of TLR9, and not other TLRs in Introduction as well as in the Discussion.

2. It is well established that the causative agent for cervical cancer is due to infection of specific types of high risk Human papillomaviruses. Any study on cervical cancer demands for an obvious correlation/association with HPV status of the cervical cancer. If at all no HPV analysis has been done, the authors must discuss this in the Discussion.

3. There are several English and grammatical errors throughout the manuscript. Authors need to carefully re-read the manuscript and correct the manuscript. Few obvious errors are indicated here:-

i) Methods: $3^{\text {rd }}$ line: reaction and restriction fragment length 
ii)Conclusion: $1^{\text {st }}$ line - the present study demonstrates no involvement - (delete 'results'), 3 rd line - delete 'worldwide' and in $4^{\text {th }}$ line - delete 'participants', replace it with 'subjects

iii)Table 1 last column below Visualized on: write $2 \%$ Agarose gel.

4. Data set 3: delete 'unedited'.

In summary, the manuscript may be accepted for indexing after the authors made the minor revision of the manuscript as suggested above.

Is the work clearly and accurately presented and does it cite the current literature? Yes

Is the study design appropriate and is the work technically sound?

Yes

Are sufficient details of methods and analysis provided to allow replication by others? Yes

If applicable, is the statistical analysis and its interpretation appropriate? Yes

Are all the source data underlying the results available to ensure full reproducibility? Yes

Are the conclusions drawn adequately supported by the results?

Yes

Competing Interests: No competing interests were disclosed.

I confirm that I have read this submission and believe that I have an appropriate level of expertise to confirm that it is of an acceptable scientific standard, however I have significant reservations, as outlined above.

Author Response 20 Aug 2018

Alex Chauhan, Charotar University of Science and Technology, Changa, India

Dear Prof. B. C. Das,

We thank you for approving our manuscript and appreciate your valuable suggestions.

Please find below the response towards your reservations:

Reservation 1: The whole study is based on only one TLR9 gene polymorphism. Authors need to very clearly justify their choice of TLR9, and not other TLRs in Introduction as well as in the Discussion.

Response: The choice of TLR9 is based on the fact that it recognized HPV16 DNA which is a main causative agent of cervical cancer. As suggested this has been included in the introduction as well as discussion. 
Reservation 2: It is well established that the causative agent for cervical cancer is due to infection of specific types of high risk Human papillomaviruses. Any study on cervical cancer demands for an obvious correlation/association with HPV status of the cervical cancer. If at all no HPV analysis has been done, the authors must discuss this in the Discussion.

Response 2: We do agree that cervical cancer is mainly caused by the infection of hrHPVs. We found approximately $70 \%$ of our cases with HPV positivity, that has been incorporated in the discussion. The details of HPV infection will be published elsewhere.

Reservation 3: There are several English and grammatical errors throughout the manuscript. Authors need to carefully re-read the manuscript and correct the manuscript. Few obvious errors are indicated here:-

i) Methods: 3rd line: reaction and restriction fragment length ii)Conclusion: 1 st line - the present study demonstrates no involvement - (delete 'results'), 3rd line - delete 'worldwide' and in 4th line - delete 'participants', replace it with 'subjects iii)Table 1 last column below Visualized on: write $2 \%$ Agarose gel.

Response 3: The above mentioned suggestions have been incorporated.

Reservation 4: Data set 3: delete 'unedited'.

Response 4: Deleted.

Competing Interests: No competing interests were disclosed.

Reviewer Report 23 July 2018

https://doi.org/10.5256/f1000research.16153.r35718

(C) 2018 Mittal B. This is an open access peer review report distributed under the terms of the Creative Commons Attribution License, which permits unrestricted use, distribution, and reproduction in any medium, provided the original work is properly cited.

\section{Balraj Mittal}

Department of Biotechnology, Babasaheb Bhimrao Ambedkar University, Lucknow, India

The basic assumption of genetic epidemiology is that two alleles of a gene are present in the population and one of the allele (usually minor) has altered frequency in cases and controls. However, if a gene is mono-morphic as is the case here for TLR9C296T, then it is non-informative and there is no point to look for its association.

Therefore, the very basis of study is wrong, even though it has been carried out technically correct.

I therefore feel that this publication will not anything the present knowledge.

Is the work clearly and accurately presented and does it cite the current literature? 
Yes

Is the study design appropriate and is the work technically sound?

No

Are sufficient details of methods and analysis provided to allow replication by others? Yes

If applicable, is the statistical analysis and its interpretation appropriate? Partly

Are all the source data underlying the results available to ensure full reproducibility? Yes

Are the conclusions drawn adequately supported by the results? Partly

Competing Interests: No competing interests were disclosed.

I confirm that I have read this submission and believe that I have an appropriate level of expertise to state that I do not consider it to be of an acceptable scientific standard, for reasons outlined above.

Reviewer Report 25 June 2018

https://doi.org/10.5256/f1000research.16153.r34771

(C) 2018 Narayan G. This is an open access peer review report distributed under the terms of the Creative Commons Attribution License, which permits unrestricted use, distribution, and reproduction in any medium, provided the original work is properly cited.

\section{Gopeshwar Narayan}

Department of Molecular and Human Genetics, Banaras Hindu University, Varanasi, India

With the global minor allele frequency of 0.0002 , the studied sample size is too small. It is interesting to observe that there is only one genotype (homozygous wild type) present in the studied cohort. The power of the study should be mentioned by the authors. The conclusion drawn from the limited data set may not reflect the real situation. I suggest the authors to first calculate the number of samples required for the study on the basis of the frequency of minor/major alleles to achieve about $80 \%$ power of study and increase the sample size accordingly.

Is the work clearly and accurately presented and does it cite the current literature? Yes

Is the study design appropriate and is the work technically sound? 
Partly

Are sufficient details of methods and analysis provided to allow replication by others? Yes

If applicable, is the statistical analysis and its interpretation appropriate?

Yes

Are all the source data underlying the results available to ensure full reproducibility?

Yes

Are the conclusions drawn adequately supported by the results?

Partly

Competing Interests: No competing interests were disclosed.

I confirm that I have read this submission and believe that I have an appropriate level of expertise to confirm that it is of an acceptable scientific standard, however I have significant reservations, as outlined above.

Author Response 29 Jun 2018

Alex Chauhan, Charotar University of Science and Technology, Changa, India

Dear Dr. Gopeshwar Narayan,

We thank you for approving our manuscript and appreciate your valuable suggestions. Please find below the response towards your reservations:

Reservation: With the global minor allele frequency of 0.0002 , the studied sample size is too small. It is interesting to observe that there is only one genotype (homozygous wild type) present in the studied cohort. The power of the study should be mentioned by the authors. The conclusion drawn from the limited data set may not reflect the real situation. I suggest the authors first to calculate the number of samples required for the study on the basis of the frequency of minor/major alleles to achieve about $80 \%$ power of study and increase the sample size accordingly.

Response: Due to the complete absence of minor allele, the power of present study cannot be calculated. However, considering the global minor allele frequency of 0.0002 of the SNP, we calculated the power of study using Online Sample Size Estimator which was found to be $3.6 \%$. To achieve $80 \%$ power of study approximately 40000 cases and controls are required. It is presently not possible for us to collect and analyze such a larger sample size. Studies on Pro99Leu polymorphism with similar sample size and results have also been reported by Kubarenko et al., 2010 and Lee et al., 2006, which have been cited in the article.

Competing Interests: No competing interests were disclosed 
The benefits of publishing with F1000Research:

- Your article is published within days, with no editorial bias

- You can publish traditional articles, null/negative results, case reports, data notes and more

- The peer review process is transparent and collaborative

- Your article is indexed in PubMed after passing peer review

- Dedicated customer support at every stage

For pre-submission enquiries, contact research@f1000.com 